\title{
OCENA POSTRZEGANIA GLOBALNEJ STRATEGII PRZEZ PRACOWNIKÓW DUŻYCH PRZEDSIĘBIORSTW
}

DOI: 10.33141/po.2021.3.02

\section{Mariusz Urbański}

\section{Wprowadzenie}

G lobalna strategia sprowadza się do polityki i planów opracowanych przez organizację w celu osiągnięcia wzrostu wykraczającego poza wyznaczone ograniczenia i obszary (Wolfmayr, 2020). Realizacja strategii globalnej przez dane przedsiębiorstwo jest jednym z warunków funkcjonowania przedsiębiorstwa globalnego (Kucharski, Majewski, 2006). Tego typu firmy prowadzą skoordynowane działania, które polegają na integracji strategii lokalnej i międzynarodowej oraz jej implementacji na poziomie globalnym poprzez maksymalnie skuteczne wykorzystanie swoich zasobów. Jednym z kluczowych zasobów każdego przedsiębiorstwa jest kapitał ludzki, który odzwierciedla zbiór kompetencji, wiedzy i umiejętności pracowników.

Pracownicy to najcenniejszy zasób każdej organizacji (Wisse i in., 2018) i w związku z tym stanowią ważny element realizacji globalnej strategii przedsiębiorstwa. Zakłada się, że świadomość pracowników w obszarze prowadzonych $\mathrm{w}$ ich przedsiębiorstwach działań i celów na skalę międzynarodową zwiększa skuteczność realizacji globalnej strategii. Dokonana niżej analiza literatury wykazała, że rozważania w tym temacie są dość powszechne i częste, jednakże nie ukazują one problemu z punktu widzenia kadry pracowniczej zatrudnionej na różnych szczeblach zarządzania organizacją. Dlatego za cel artykułu przyjęto zbadanie poziomu wiedzy pracowników dużych przedsiębiorstw $\mathrm{w}$ zakresie realizowanej $\mathrm{w}$ ich podmiocie strategii zarządzania na poziomie globalnym.

\section{Przegląd literatury}

\section{Przedsiębiorstwa na globalnym rynku}

G lobalizacja rynków spowodowała, że wiele przedsiębiorstw znalazło nowe źródło przychodów za granicą. Rynek globalny oferuje znaczące potencjalne korzyści, takie jak przystępne warunki obniżenia kosztów, dostęp do nowych klientów i konsumentów czy też dywersyfikację ryzyka. $Z$ uwagi na budowaną i permanentnie rozwijaną sieć współpracy relatywnie największy udział w obcych rynkach mają duże przedsiębiorstwa. Pracują one nad globalną strategią nie tylko po to, aby zdobywać przewagę konkurencyjną i osiągać wysokie wyniki finansowe, ale także aby budować swoją markę na światowym rynku (Addison i in., 2020). Większość organizacji działa globalnie, ponieważ zwiększa to ich rentowność i poziom
Przegląd Organizacji, Nr 2(973), 2021, s. 12-19

www.przegladorganizacji.pl ๑) Towarzystwo Naukowe Organizacji i Kierownictwa (TNOiK) sprzedaży (Chisholm i in., 2018). Spośród nich wyróżnić można:

- przedsiębiorstwa globalne definiowane jako organizacje, które posiadają swoje obiekty, tj.: przedstawicielstwa, centra dystrybucyjne i fabryki w różnych krajach na całym świecie (Banacki, Gorynia, 2013);

- przedsiębiorstwa międzynarodowe, których produkty sprzedawane są na całym świecie, mimo że ich zakłady działają tylko w kraju macierzystym (Haller, 2016).

Niezależnie od charakteru, obydwa typy przedsiębiorstw muszą realizować określoną strategię o zasięgu globalnym, aby zapewnić efektywność działalności na rynkach zewnętrznych. Co więcej stanowi ona odpowiedź na współzależny charakter rynków globalnych, na których konkurencja powinna być rozpatrywana jednolicie bez uwzględniania jej wielonarodowości.

\section{Strategia globalna w świetle zarządzania dużym przedsiębiorstwem}

Możliwość generowania zysków z zewnątrz wymaga podjęcia konkretnych i skutecznych działań o zasięgu globalnym, za które odpowiada globalna strategia zarządzania przedsiębiorstwem (Lisiński i in., 2012). Ma ona na celu zwiększenie sprzedaży za granicą i wzrost wymiany handlowej pomiędzy przedsiębiorstwami z różnych krajów przez systematyczny rozwój i wdrażanie planu ustalonego dla międzynarodowej lub wielonarodowej dystrybucji towarów lub usług. W odniesieniu do rodzaju organizacji strategia globalna ma cztery główne cele (Carpenter i in., 2003):

1) globalne wzmocnienie, wdrożenie i rozwój;

2) wzrost intensywności działań rzeczywistych;

3) wdrażanie polityki regionalnej i międzynarodowej;

4) ustanawianie zaangażowania pomiędzy wszystkimi sektorami.

Realizacja globalnej strategii zarządzania w organizacji niosie ze sobą liczne korzyści widoczne w możliwości nawiązywania kontaktów z producentami z całego świata, kreowaniu partnerstwa $\mathrm{z}$ organizacjami międzynarodowymi, zabezpieczaniu kursów wymiany walut, inwestycjach zagranicznych oraz imporcie usług lub towarów w celu poprawy wyników na rynku krajowym. Dzięki współpracy z międzynarodowymi partnerami, do których należą klienci, dostawcy i dystrybutorzy, oraz zdobytym 
na jej drodze licznym informacjom poprawie ulega potencjał innowacyjny przedsiębiorstwa (Iqbal, Hameed, 2020). Co więcej, organizacje działające na rynku międzynarodowym posiadają lepszą gotowość do zmian w przypadku niekorzystnych warunków biznesowych występujących na danym rynku (Wiśniewska-Placheta, 2005). Badania K. Krzywickiej-Szpor (2003) udowodniły, że takie działanie powoduje wzrost osobistego zaangażowania i zmotywowania kadry do realizacji zadań opartej na wzajemnej współpracy. Skłania to do zbadania poziomu świadomości i zaangażowania pracowników w realizację globalnej strategii ich przedsiębiorstwa.

\section{Rola kapitału ludzkiego w realizowaniu skutecznej strategii globalnej przedsiębiorstwa}

Przeprowadzone dotychczas badania wykazały, że świadomość pracowników na temat wdrażanych planów i projektów odgrywa istotną rolę w dążeniu do sukcesu organizacji (Lukitowati, Ramli, 2020; Rotvold, 2008). Wydaje się więc konieczne, aby pracownicy zatrudnieni w przedsiębiorstwie działającym na skalę globalną posiadali także wiedzę na temat globalnej strategii zarządzania. Osobiste zaangażowanie pracowników w proces wdrażania globalnej strategii organizacji ma na celu maksymalizację osiąganych przez nią wyników finansowych. Proces ten wymaga dobrej znajomości umiejętności i kompetencji zasobów ludzkich, co umożliwia lepsze wykorzystanie posiadanego potencjału i zwiększa morale całego zespołu. W tym celu realizowana jest także odrębna strategia alokacji zasobów, której celem jest nawiązanie pozytywnych relacji między pracownikami poprzez kreowanie przyjaznego środowiska pracy. Pracownicy przechodzą wstępne szkolenie, które pozwala im poznać i przygotować się na potrzeby i wymagania swojego pracodawcy (Tahir i in., 2014) w celu rozwijania i prowadzenia działalności między innymi na rynkach zagranicznych. Podejmowane w tym zakresie działania mają pobudzać pracowników do zwiększania własnej produktywności, która przekłada się na wydajność całej organizacji.

W kontekście tym ujawnia się potrzeba zarządzania wiedzą prowadzona przez przedsiębiorstwo, która ma decydujące znaczenie dla kształtowania świadomości pracowników i pomaga kreować głębokie związki pomiędzy organizacją i jej pracownikami (Al-Dmour i in., 2020). Pracownicy posiadający niezbędną wiedzę na temat ogólnego funkcjonowania swojej organizacji są jednocześnie w sposób uporządkowany i przejrzysty informowani o swoich funkcjach i efektywności pracy. Świadomość zadań związanych z realizacją globalnej strategii motywuje kadrę do lepszego wykorzystania swojego potencjału w celu rozwoju całego przedsiębiorstwa. Z kolei pracownicy, którzy nie posiadają wystarczającej wiedzy na temat globalnej strategii swojej organizacji, mogą wykazywać mniejsze zaangażowanie w jej realizację.

Zaangażowanie jest kluczowym elementem utrzymania żywotności organizacji, jej przetrwania i zapewnienia rentowności (Albercht i in., 2015; Farndale, Murrer, 2015). T. Stoyanova i I. Iliev (2017) w swoich badaniach skupiają się na metodach angażowania pracowników, którzy są nie- zbędni w dążeniu do realizacji celów organizacyjnych i dlatego powinni być połączeni fizycznie, psychicznie i emocjonalnie $\mathrm{z}$ organizacją, $\mathrm{w}$ której pracują. Z kolei M. Michna (2016) zauważa, że zasoby ludzkie to ważny czynnik przewagi konkurencyjnej, który stanowi kluczowy cel strategii globalnej. Motywowanie zasobów ludzkich do rozwoju poprzez tworzenie odpowiedniego środowiska pracy wpływa na zwiększenie poziomu wydajności całego przedsiębiorstwa, ale wymaga także odpowiedniego przygotowania kadry opartego na procedurach i długoterminowych wynikach (Vosloban, 2012; Malewska, Sajdak, 2020).

Analiza literatury wykazała, że temat zarządzania zasobami ludzkimi jest najczęściej sprzężony z ogólną strategią zarządzania przedsiębiorstwem. W licznych badaniach zwraca się szczególną uwagę na zaangażowanie pracowników w rozwój firmy, nie skupiając się konkretnie na wdrażaniu strategii globalnej. Rozważania te pozwalają zakładać, że wiedza i świadomość pracowników są kluczowymi czynnikami przewagi konkurencyjnej firmy także w skali globalnej. Konstatując, w dalszej części podjęto badania w zakresie identyfikacji poziomu świadomości pracowników w odniesieniu do strategii globalnej przedsiębiorstw, w których są oni zatrudnieni.

\section{Metoda badawcza}

C el badania został zrealizowany w wyniku przeprowadzenia analizy i oceny danych pierwotnych (Chan i in., 2019). Dane te zostały zebrane za pomocą kwestionariusza ankiety w okresie jednego miesiąca wśród pracowników dużych firm (zatrudniających więcej niż 250 osób), które posiadają główną siedzibę w Polsce. Zgodnie z danymi COIG, w Polsce swoją działalność prowadzi ponad 4 tys. dużych przedsiębiorstw sektora prywatnego (Centralny Ośrodek Informacji Gospodarczej, 2021). Stanowią one około 0,2\% wszystkich firm w Polsce i w przeważającej większości prowadzą działalność na rynku międzynarodowym. Pytaniem determinującym dobór przedsiębiorstwa do próby było zadeklarowanie wdrażania strategii globalnej w danej firmie, które zadano wybranym losowo pracownikom spośród 350 podmiotów (minimalna wielkość próby dla $5 \%$ błędu maksymalnego i $\alpha=0,95)$. Na podstawie wstępnego etapu doboru próby jedynie w 200 przedsiębiorstwach zadeklarowano stosowanie strategii globalnej i to do nich skierowano finalnie pełny kwestionariusz badawczy drogą elektroniczną (Altaf $\mathrm{i}$ in., 2019). W odpowiedzi zwrotnej uzyskano 82 kompletne kwestionariusze badawcze. W każdym ze zbadanych podmiotów odpowiedzi udzielał jeden delegowany do tego pracownik.

Kwestionariusz badawczy został podzielony na dwie główne części, które obejmowały metryczkę oraz kluczowe dla realizacji celu pytania. Pozyskane $\mathrm{w}$ ten sposób dane wykorzystano do dalszej szczegółowej analizy częstotliwości wskazań. Zaprezentowano strukturę odpowiedzi i ich analizę w aspekcie oceny poziomu świadomości pracowników w obszarze globalnej strategii przedsiębiorstwa. Dokonano także analizy sposobów angażowania $\mathrm{i}$ informowania pracowników o planach i celach przedsiębiorstwa. 


\section{Wyniki badań}

\section{Analiza próby badawczej}

Z godnie z otrzymanymi wynikami, najczęściej udział $\mathrm{w}$ badaniu brali pracownicy $\mathrm{z}$ przedsiębiorstw handlowych (31\%), a następnie kolejno $\mathrm{z}$ przedsiębiorstw transportowych (24\%), usługowych $(21 \%)$ i produkcyjnych (20\%). Najmniejszą liczbę przedsiębiorstw w próbie badawczej stanowiły te $\mathrm{z}$ sektora budowlanego (2\%) i wydobywczego (2\%). Jednocześnie okres pracy w firmie dla większości respondentów wynosił od 3 miesięcy do 5 lat (64\%). Co piąty badany pracownik zatrudniony jest w swoim przedsiębiorstwie ponad 5 lat (20\%), a najmniej badanych pracowników pracuje w nim krócej niż 3 miesiące (8\%). Większość osób udzielających odpowiedzi zajmowała stanowisko specjalisty (46\%). Nieco mniej odpowiedzi udzieliła grupa pracowników najniższego szczebla (29\%). Osoby na stanowiskach kierowniczych oraz kadra zarządzająca stanowiła odpowiednio 18\% i 6\% ogółu badanej próby. Wysoki udział pracowników spoza kadry kierowniczej umożliwia zidentyfikowanie świadomości realizacji strategii globalnej wśród pracowników, którzy posiadają najmniejszy dostęp do zasobów firmy. Staż pracy, jak też stanowisko pracownika przekładają się na dostęp do danych firmy oraz zdobyte doświadczenie i kompetencje, co może oddziaływać na posiadaną wiedzę pracowników o wdrażanej strategii globalnej.

\section{Poziom strategii globalnej}

Zadaniem kolejnej części badania było określenie podstawowej wiedzy pracownika $\mathrm{z}$ zakresu międzynarodowej działalności przedsiębiorstwa, w którym jest zatrudniony. Pozyskane z kwestionariusza wyniki pozwoliły zaobserwować, że więcej niż $95 \%$ badanych podmiotów realizuje współpracę z partnerami zagranicznymi (tab. 1).

Tabela 1. Zakres współpracy badanych przedsiębiorstw z zagranicznymi partnerami

\begin{tabular}{|l|c|}
\hline Rodzaje partnerów zagranicznych & $\begin{array}{c}\text { Struktura } \\
\text { wskazań [\%] }\end{array}$ \\
\hline Klienci & 80,49 \\
\hline Dostawcy & 78,05 \\
\hline Usługodawcy logistyczni & 67,07 \\
\hline Inni usługodawcy zewnętrzni & 48,78 \\
\hline $\begin{array}{l}\text { Przedsiębiorstwo nie współpracuje } \\
\text { z zagranicznymi partnerami }\end{array}$ & 4,88 \\
\hline
\end{tabular}

Źródło: opracowanie własne

Według opinii przebadanych pracowników, ich przedsiębiorstwa najczęściej współpracują z zagranicznymi klientami (80\% wskazań), co argumentuje konieczność podjęcia właściwej strategii marketingowej zależnie od potrzeb danego rynku. Drugim z kolei najczęściej wybieranym partnerem zagranicznym są dostawcy (78\%) oraz usługodawcy logistyczni (67\%). Świadczy to o tym, że przedsiębiorstwa te chętnie rozwijają swoją sieć biznesową na poziomie międzynarodowym celem poszukiwania przewagi konkurencyjnej. Ponad połowa pracowników wskazała na kooperację ich pracodawcy z zagranicznymi dostawcami innych usług niż logistyczne (48\%). Jedynie niecałe $5 \%$ pracowników twierdzi, że ich firma nie kooperuje z zagranicznymi partnerami biznesowymi. Oznacza to, że pracownicy ci nie posiadają świadomości o tego rodzaju współpracy i w związku z tym nie mają oni wiedzy na temat celów dotyczących ekspansji ich firmy na obce rynki.

Zdecydowana większość pracowników była w stanie określić, że firma, w której pracują, posiada globalną strategię (76\%). Niestety, duży odsetek pracowników nie był w stanie określić, czy ich przedsiębiorstwo realizuje taki rodzaj strategii (17\%) lub zdecydowanie zaprzeczyła, aby tak faktycznie było (6\%). Oznacza to, że co czwarty badany pracownik nie jest w pełni świadomy, jak i na jaką skalę przebiega rozwój jego organizacji.

Analizując strukturę odpowiedzi (rys. 1) odnośnie do postrzegania przez pracownika globalnej strategii, zauważa się, że zdecydowana większość z nich pozytywnie ocenia konieczność jej wdrażania w swoim przedsiębiorstwie (średnio 68\% udziału w kategorii odpowiedzi: zgadzam się i całkowicie się zgadzam). Co piąty pracownik nie potrafi wyrazić konkretnej opinii na ten temat (średnio 20\% udziału w kategorii odpowiedzi: ani się zgadzam, ani się nie zgadzam). Jedynie około $10 \%$ badanej kadry (średni udział wskazań w kategorii całkowicie się nie zgadzam i nie zgadzam się) nie widzi potrzeby wdrażania działań dedykowanych rozwojowi na rynku globalnym.

Analizując wyniki zawarte na wykresie, obserwuje się, że według ponad połowy badanych pracowników wdrażana w ich przedsiębiorstwie globalna strategia jest odpowiednio dostosowana do współczesnych trendów marketingowych (62\% wskazań w kategorii „całkowicie się zgadzam” i „zgadzam się"). Prawie co dziesiąty pracownik ma przeciwne zdanie, uważając, że realizowana strategia nie odpowiada aktualnym potrzebom rynku (10\% wskazań w kategorii „całkowicie się nie zgadzam” i „nie zgadzam się”). Jednocześnie dla mniej niż połowy zatrudnionych świadomość wdrażania $\mathrm{w}$ ich firmie globalnej strategii wpływa na ich motywację do pracy (41\% pozytywnych wskazań). Z kolei co piąty pracownik przyznaje, że świadomość ta nie zmienia jego podejścia do wykonywanej pracy (20\%). Zdecydowana większość respondentów uważa, że lokalizacja biznesu jest ważna w kontekście globalnej strategii (72\% pozytywnych wskazań). Ponad $8 \%$ pracowników uznaje z kolei miejsce realizacji działalności za nieznaczące przy planowaniu i wdrażaniu globalnej strategii. Jeszcze więcej pracowników przyznaje, że posiadanie globalnej strategii jest korzystne (85\% pozytywnych wskazań) i ważne (87\% pozytywnych wskazań) dla przedsiębiorstwa. Jedynie około 8\% (łączny udział negatywnych wskazań dla obu odpowiedzi) badanej kadry stwierdza z kolei, że strategia ta jest niekorzystna lub nieważna w działalności podmiotu. Niewiele więcej niż połowa pracowników badanych dużych organizacji wykazuje jednocześnie zainteresowanie jej globalną strategią ( $54 \%$ pozytywnych wskazań). Prawie co piąty pracownik (18\% wskazań) nie widzi potrzeby angażowania się w realizację globalnej strategii firmy. 


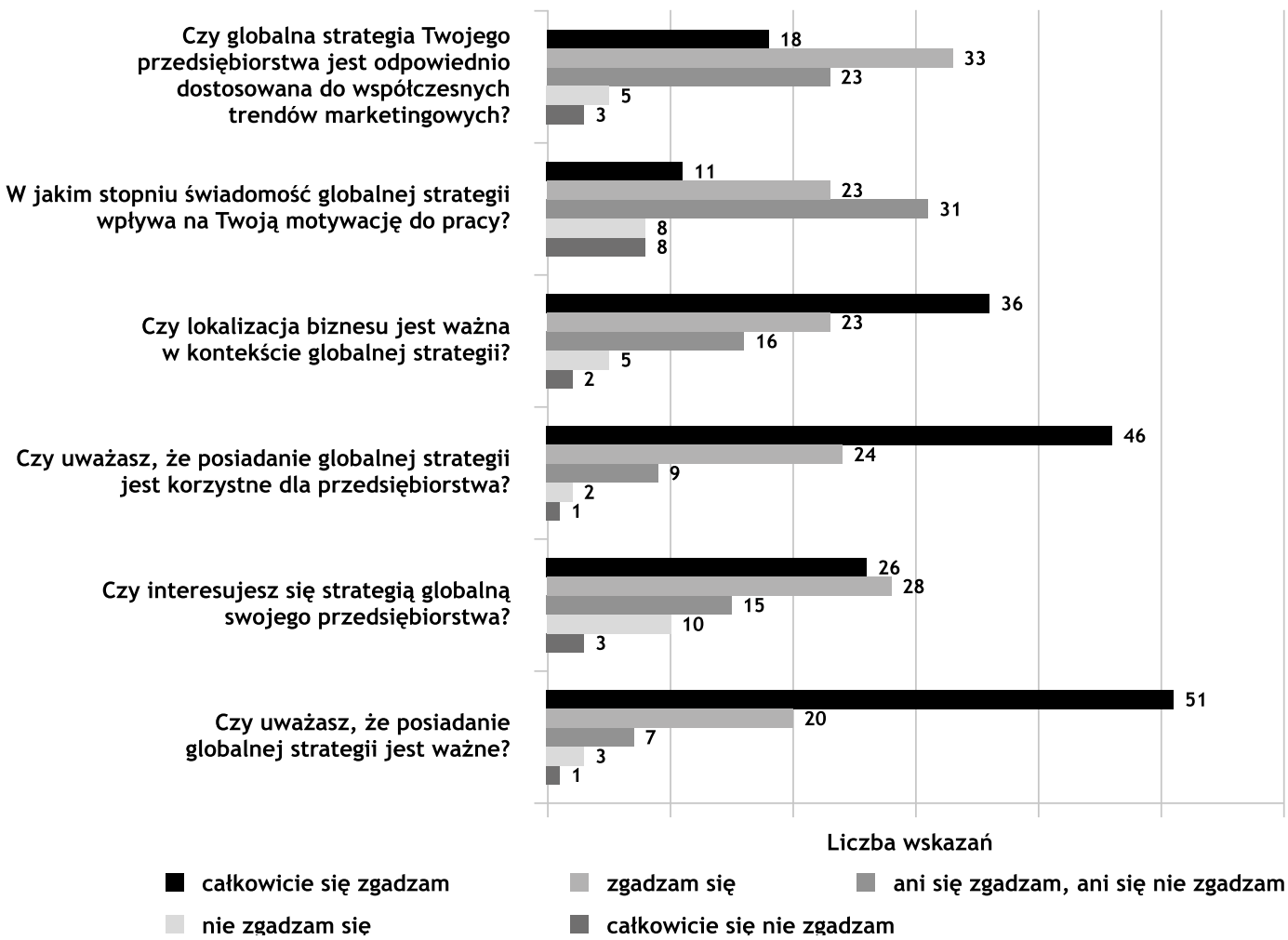

Rys. 1. Postrzeganie koncepcji strategii globalnej przez pracowników dużych przedsiębiorstw Źródto: opracowanie wtasne

Tabela 2. Główne cele globalnej strategii w badanych przedsiębiorstwach

\begin{tabular}{|l|c|c|}
\hline \multicolumn{1}{|c|}{ Cele globalnej strategii } & Struktura wskazań [\%] & Liczba wskazań \\
\hline Ekspansja na nowe rynki & 28 & 23 \\
\hline Budowanie marki & 20 & 16 \\
\hline Wdrażanie innowacji & 20 & 16 \\
\hline Efektywność i wyniki & 16 & 13 \\
\hline Adaptacja & 6 & 5 \\
\hline Zarządzanie ryzykiem & 5 & 4 \\
\hline Dywersyfikacja dostawców & 4 & 3 \\
\hline Świadczenie usługi na wysokim poziomie & 1 & 1 \\
\hline $\begin{array}{l}\text { Moje przedsiębiorstwo jest lokalnym graczem, nie ma } \\
\text { strategii globalnej }\end{array}$ & 1 & 1 \\
\hline Razem & 100 & 82 \\
\hline
\end{tabular}

Źródło: opracowanie wtasne

Wstępne wyniki pokazują, że pracownicy dużych firm są świadomi wdrażania globalnej strategii przez ich pracodawców oraz jej znaczącego wpływu na działalność. Mimo to świadomość istnienia strategii nie wpływa istotnie na większe zaangażowanie pracowników do realizacji zadań $\mathrm{z}$ nią związanych. Jednocześnie $\mathrm{w}$ przypadku prawie co trzeciego pracownika obserwuje się niezdecydowanie co do opinii na temat dostosowania strategii globalnej ich firmy do współczesnego marketingu. Może to świadczyć o niskim poziomie wiedzy na temat wdrażanych planów i działań na rynkach międzynarodowych.
Jednocześnie pracownicy pytani o główny cel globalnej strategii ich przedsiębiorstwa w zdecydowanej większości nie mieli problemu ze wskazaniem konkretnej odpowiedzi (tab. 5). Najczęściej wskazywali chęć ekspansji ich firmy na nowe rynki (28\%).

Ekspansja międzynarodowa to sposób na znaczne przyspieszenie rozwoju przedsiębiorstwa, stąd udział w międzynarodowych rynkach badanych przedsiębiorstw stanowi najważniejszy kierunek ich działania. Co piąty pracownik wskazywał także na cel budowania marki lub wdrażania innowacji (średnio $20 \%$ wskazań). Świadczy to o potrzebie bycia 
Tabela 3. Najważniejsze warunki realizacji globalnej strategii w przedsiębiorstwie

\begin{tabular}{|l|c|c|}
\hline \multicolumn{1}{|c|}{ Warunki realizacji globalnej strategii } & Struktura wskazań [\%] & Liczba wskazań \\
\hline Wdrażanie innowacji & 34 & 28 \\
\hline Dążenie do zrównoważonego rozwoju & 26 & 21 \\
\hline Zaawansowana infrastruktura technologiczna & 20 & 8 \\
\hline Integracja obszarów & 10 & 8 \\
\hline Uczenie się przez całe życie & 10 & 1 \\
\hline Konsekwencja w dążeniu do celów & 1 & 82 \\
\hline Razem & 100 & 8 \\
\hline
\end{tabular}

Źródto: opracowanie wtasne

Tabela 4. Najważniejsze zalety stosowania globalnej strategii

\begin{tabular}{|l|c|c|}
\hline \multicolumn{1}{|c|}{ Zalety globalnej strategii } & Struktura wskazań [\%] & Liczba wskazań \\
\hline Wzrost zysku & 18 & 39 \\
\hline Rozpoznawanie marki & 17 & 37 \\
\hline Lepsza jakość produktów i programów & 16 & 34 \\
\hline Wzrost sprzedaży & 16 & 29 \\
\hline Zwiększona efektywnóś w odniesieniu do realizacji potrzeb klienta & 14 & 21 \\
\hline Redukcja kosztów & 10 & 18 \\
\hline Zwiększony efekt dźwigni konkurencyjnej & 8 & 212 \\
\hline Razem & 100 & 212 \\
\hline
\end{tabular}

Źródto: opracowanie wtasne

przez firmę rozpoznawalną na globalnym rynku, ale i chęci dorównania światowej konkurencji poprzez ciąłe wdrażanie nowych rozwiązań. Duży udział wskazań miała także chęć dążenia do efektywności i osiągania lepszych wyników (16\%) zarówno w obszarze finansów, jak i ogólnej wydajności działalności badanych przedsiębiorstw. Zdecydowanie rzadziej celami globalnej strategii $\mathrm{w}$ badanych przedsiębiorstwach były adaptacja $\mathrm{w}$ międzynarodowym otoczeniu (6\%), zarządzanie ryzykiem (5\%) czy dywersyfikacja dostawców (4\%).

$\mathrm{Z}$ danych przedstawionych $\mathrm{w}$ tabeli 3 wynika, że większość zatrudnionych uważa za najważniejszą w realizacji globalnej strategii działalność innowacyjną (34\%), która stanowi jednocześnie jeden z częstszych celów tej strategii. Kolejnym istotnym czynnikiem według badanej grupy jest dążenie do zrównoważonego rozwoju (26\%). Co piąty pracownik za istotne uznaje także zapewnienie odpowiedniego zaawansowania infrastruktury technologicznej wykorzystywanej w działalności operacyjnej swojego przedsiębiorstwa (20\%). Nieco rzadziej za ważny warunek skutecznej realizacji strategii globalnej uznano integrację obszarów i uczenie się przez całe życie (średnio 10\%).

Uzyskane wyniki świadczą o konieczności wdrażania innowacji jako podstawowego warunku rozwoju przedsiębiorstwa na rynku międzynarodowym z uwzględnieniem działań podejmowanych na rzecz zrównoważonego rozwoju, który nie tylko koncentruje się zarówno na potrzebach przedsiębiorstwa, jak i ochronie zasobów ludzkich i naturalnych. Uzupełnieniem tych działań jest dostępność odpowiedniego zaplecza technologicznego, która zapewnia wysoką jakość produktów i usług.
W realizacji każdej strategii ważną rolę odgrywa zaangażowanie pracownika, co może oddziaływać na finalne wyniki całego przedsiębiorstwa (rys. 2).

Według zebranych opinii, pracownicy badanych przedsiębiorstw najczęściej potrzebują zaufania i zaangażowania ze strony pracodawców (93\% wskazań w kategorii „bardzo ważne i „ważne”) oraz informowania ich o zrealizowanych etapach lub działaniach podejmowanych na rzecz realizacji globalnej strategii (91\% wskazań pozytywnych). Tylko nieco rzadziej istotne było stosowanie motywacyjnego systemu wynagrodzeń opartego na celach globalnej strategii firmy (84\% wskazań pozytywnych), procesu wspierającego porównywalną pracę za granicą ( $84 \%$ wskazań pozytywnych) oraz wybór języka używanego w strukturach przedsiębiorstwa (81\%).

Co więcej, według badanych pracowników najważniejszą zaletą stosowania globalnej strategii $\mathrm{w}$ ich przedsiębiorstwie (tab. 4) jest jej wkład w zwiększenie zysków (18\%), rozpoznawalność marki (17\%), wzrost sprzedaży (16\%) oraz lepsza jakość produktów i programów (16\%). Zwiększoną efektywność w odniesieniu do realizacji potrzeb klientów na skutek wdrożenia strategii dostrzega $14 \%$ badanych. Jedynie co dziesiąty pracownik zaobserwował redukcją ogólnych kosztów działalności (10\%). Najmniejsze korzyści płynące z globalnej strategii zauważane są w obszarze zwiększonej dźwigni konkurencyjnej (8\%).

Ponad połowa pracowników otrzymuje wsparcie ze strony pracodawcy na rzecz poszerzania swojej wiedzy na temat globalnej strategii realizowanej w ich przedsiębiorstwie (66\%). Pozostali nie potrafią tego ocenić (18\%) lub wyraźnie deklarują, że ich pracodawca takiej możliwości im nie oferuje (16\%). 


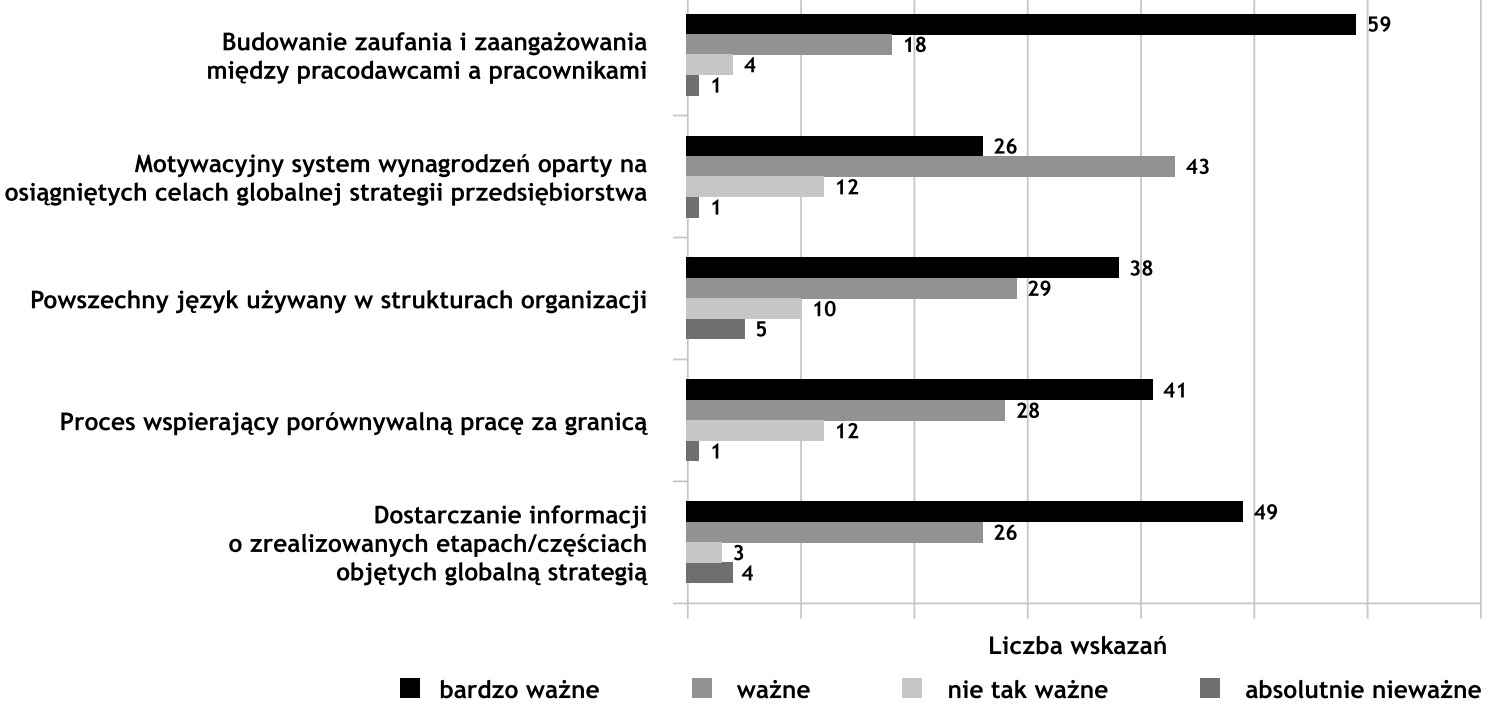

Rys. 2. Działania wspierające pracowników w realizacji globalnej strategii Źródto: opracowanie własne

Tabela 4. Najważniejsze zalety stosowania globalnej strategii

\begin{tabular}{|l|c|c|}
\hline \multicolumn{1}{|c|}{ Zalety globalnej strategii } & Struktura wskazań [\%] & Liczba wskazań \\
\hline Wzrost zysku & 18 & 39 \\
\hline Rozpoznawanie marki & 17 & 37 \\
\hline Lepsza jakość produktów i programów & 16 & 34 \\
\hline Wzrost sprzedaży & 16 & 29 \\
\hline Zwiększona efektywność w odniesieniu do realizacji potrzeb klienta & 14 & 21 \\
\hline Redukcja kosztów & 10 & 18 \\
\hline Zwiększony efekt dźwigni konkurencyjnej & 8 & 212 \\
\hline Razem & 100 & \\
\hline
\end{tabular}

Źródto: opracowanie własne

Tabela 5. Sposoby rozpowszechniania wiedzy o strategii, wizji, misji, nowościach i zmianach w badanych przedsiębiorstwach

\begin{tabular}{|l|c|c|}
\hline \multicolumn{1}{|c|}{ Sposoby rozpowszechniania strategii } & Struktura wskazań [\%] & Liczba wskazań \\
\hline Wewnętrzny system informacyjny & 36 & 29 \\
\hline Wiadomości e-mail & 32 & 26 \\
\hline Media społecznościowe (FB, Instagram) & 15 & 6 \\
\hline Powiadomienia ustne - odbierane i przekazywane przez pracowników & 7 & 6 \\
\hline Od bezpośredniego przełożonego & 7 & 2 \\
\hline Inne (zebrania firmowe) & 2 & 1 \\
\hline Inne (Wszystkie źródła wykorzystujące Internet) & 1 & 82 \\
\hline Razem & 100 & \\
\hline
\end{tabular}

Źródto: opracowanie własne

Świadomość i wiedza pracownika z zakresu realizowanej strategii globalnej w jego przedsiębiorstwie, na którą składają się różnego rodzaju działania, plany i wizje, może być rozwijana różnymi kanałami komunikacyjnymi, które uwzględniają zarówno pośrednią, jak i bezpośrednią wymianę komunikatów (tab. 5).

Najczęściej wiedza o strategii, wizji, misji, nowościach i zmianach w badanych przedsiębiorstwach rozpowszech- niana jest poprzez wykorzystanie wewnętrznego systemu informacyjnego (36\% wskazań). Komunikatory korporacyjne stanowią jeden ze skuteczniejszych kanałów wymiany informacji między pracownikami różnych szczebli i stanowisk. Ważne miejsce zajmuje także procesy wymiany informacji drogą mailową (32\%). Są to dwa najbardziej powszechne kanały komunikacji. Zdecydowanie rzadziej pracownicy dowiadują się o planach i działaniach swojego pracodawcy 
poprzez media społecznościowe (15\%), które stanowią obecnie ważne narzędzie promocji w sieci. Najrzadziej informacje przekazywane są ustnie (7\%), w drodze od bezpośredniego przełożonego (7\%) czy na zebraniach firmowych (2\%).

\section{Podsumowanie}

$\mathbf{Z}$ realizowane badania pozwolity dokonać pewnych obserwacji, które w ogólnym ujęciu wykazały, że większość pracowników badanych dużych przedsiębiorstw posiada świadomość realizowania współpracy międzynarodowej przez ich firmę poprzez wdrażanie odpowiedniej strategii globalnej. Jej celem najczęściej jest ekspansja na nowe rynki i budowanie marki oraz wspieranie działalności innowacyjnymi rozwiązaniami. Skuteczność wdrażanej strategii obserwuje się głównie w poziomie generowanych zysków i rozpoznawalności marki na świecie. Większość pracowników otrzymuje czynne wsparcie w zakresie pogłębiania wiedzy z zakresu realizowanej strategii zazwyczaj poprzez wykorzystanie wewnętrznego systemu obiegu informacji w organizacji. Oznacza to, że większość pracowników dużych firm posiada świadomość realizowania strategii globalnej i zna szczegóły tego procesu.

Przeprowadzone badania udowodniły, że duże przedsiębiorstwa zmierzają w kierunku globalnej strategii, czego świadomość posiada zdecydowana większość zatrudnionych w nich kadry. Niemniej jednak pewna niewielka część pracowników wskazuje, że nie mają oni pojęcia o strategii globalnej swoich przedsiębiorstw. Wśród dużych podmiotów można zidentyfikować niewielką część kadry, która nie posiada wiedzy o działalności ich firmy na rynku globalnym, co może negatywnie wpływać na skuteczny proces ekspansji. Średnio co piąty pracownik nie jest w stanie określić, czy i jak jego przedsiębiorstwo realizuje strategię globalną i co więcej, nie widzi on potrzeby angażowania się w realizację globalnej strategii firmy. Z kolei około jedna trzecia pracowników nie potrafi ocenić pozytywnego wpływu strategii na działalność ich firmy. Brak wiedzy wśród części kadry na temat przebiegu oraz skutków wdrażania założeń i celów organizacji na rynku globalnym może być uwarunkowane brakiem wsparcia ze strony pracodawcy z zakresu rozpowszechniania informacji na temat realizowanej strategii globalnej.

Jednocześnie świadomość posiadania globalnej strategii pozwala wpływać na poziom motywacji pracowników. Zidentyfikowano, że zwiększenie zaangażowania kadry w realizację celów i wizji przedsiębiorstwa na rynku globalnym wymaga przede wszystkim zaufania i zaangażowania ze strony pracodawców oraz bieżącego informowania kadry o zrealizowanych etapach lub działaniach podejmowanych na rzecz realizacji globalnej strategii. Mniej istotny jest za to motywacyjny system wynagrodzeń oparty na celach globalnej strategii podmiotu. Rekomenduje się, aby w celu promowania strategii globalnej wśród swoich pracowników firma pracowała nad podniesieniem wydajności wewnętrznego systemu informacyjnego i obsługi mediów społecznościowych. Przeprowadzone badania ukazały, że mimo istoty świadomości celów i planów realizowanych wśród większości pracowników dużych przedsiębiorstw, nadal pozostaje wśród nich grupa, która nie posiada żadnej lub ograniczoną świadomość na temat realizowanej w ich przedsiębiorstwie globalnej strategii. Może to negatywnie wpływać na skuteczną ekspansję podmiotu na globalny rynek, dlatego wymaga większej uwagi pracodawcy celem zaangażowania pracownika w wizje i misję przedsiębiorstwa.

Przeprowadzone badanie niesie za sobą implikacje teoretyczne i praktyczne w zakresie oceny świadomości globalnej strategii wśród pracowników dużych przedsiębiorstw. Dotychczasowe analizy literaturowe nie ujmują istoty globalnej strategii z perspektywy kadry, dlatego uzyskane wyniki stanowią nowy wkład teoretyczny do dotychczasowych zasobów wiedzy. Wyniki badania mogą okazać się pomocne dla praktyków w kształtowaniu świadomości pracowników w zakresie strategii globalnej poprzez zastosowanie najlepszych metod motywacji i informowania o wdrażanych celach i planach w przedsiębiorstwie w celu osiagnięcia korzyści na skalę globalną.

Badanie posiada pewne ograniczenia. Niewątpliwie ograniczeniem badawczym jest relatywnie niewielka próba badawcza, dlatego w przyszłości należy przeprowadzić uzupełniające analizy przekrojowe świadomości pracowników różnych szczebli w przedsiębiorstwie w kontekście globalnej strategii przedsiębiorstwa wraz z uwzględnieniem wyników działalności badanych przedsiębiorstw. Interesującym przyszłym kierunkiem badań może być również analiza poziomu realizacji celów przedsiębiorstwa w kontekście świadomości pracowników na temat globalnej strategii przedsiębiorstwa.

\section{dr Mariusz Urbański Politechnika Częstochowska Wydział Budownictwa ORCID: 0000-0002-5808-5209 e-mail: mariusz.urbanski@pcz.pl}

\section{Bibliografia}

[1] Addison P., McRae L., Reuter K., Starkey M., Milner-Gulland E., Stephenson P., Burgass M. (2020), Bringing Sustainability to Life: A Framework to Guide Biodiversity Indicator Development for Business Performance Management, „Business Strategy and the Environment”, Vol. 29, No. 8, pp. 3303-3313.

[2] Albercht S.L., Bakker A.B., Gruman J.A., Macey W.H., Saks A.M. (2015), Employee Engagement, Human Resource Management Practices and Competitive Advantage: An Integrated Approach, „Journal of Organizational Effectiveness: People and Performance", Vol. 2, No. 1, pp. 7-35.

[3] Al-Dmour H.H., Asfour F., Al-Dmour R., Al-Dmour A. (2020), The Effect of Marketing Knowledge Management on Bank Performance through Fintech Innovations: A Survey Study of Jordanian Commercial Banks, „Interdisciplinary Journal of Information, Knowledge, and Management”, Vol. 15, pp. 203-225.

[4] Altaf M., Hameed W., Nadeem S., Arfan S. (2019), Successful Entrepreneurial Process as Contributor towards Business 
Performance in Banking: Moderating Role of Passion for Inventing, „South Asian Journal of Management Sciences”, Vol. 13, No. 1, pp. 130-157.

[5] Banacki P., Gorynia M. (2013), Globalność przedsiębiorstwa a koncepcja zbiorów rozmytych, „Studia Oeconomica Posnaniensia", Vol. 1, No. 1(250), s. 5-27.

[6] Carpenter M.A., Pollock T.G., Leary M.M. (2003), Testing a Model of Reasoned Risk-taking: Governance, the Experience of Principals and Agents, and Global Strategy in Hightechnology IPO Firms, „Strategic Management Journal”, Vol. 24, No. 9, pp. 803-820.

[7] Centralny Ośrodek Informacji Gospodarczej, https://www. coig.com.pl/spis-polskich-firm_katalog_polskich_firm. php, data dostępu: 15.02.2021.

[8] Chan C.M.H., Wong J.E., Yeap L.L.L., Wee L.H., Jamil N.A., Nantha Y.S. (2019), Workplace Bullying and Psychological Distress of Employees Across Socioeconomic Strata: A Cross-sectional Study, „BMC Public Health”, Vol. 19, art. 608.

[9] Chisholm D., Moro D., Bertram M., Pretorius C., Gmel G., Shield K., Rehm J. (2018), Are the „Best Buys” for Alcohol Control Still Valid? An Update on the Comparative Cost-effectiveness of Alcohol Control Strategies at the Global Level, „Journal of Studies on Alcohol and Drugs”, Vol. 79, No. 4, pp. 514-522.

[10] Farndale E., Murrer I. (2015), Job Resources and Employee Engagement: A Cross-national Study, „Journal of Managerial Psychology", Vol. 30, No. 5, pp. 610-626.

[11] Haller A.P. (2016), Globalisation, Multinational and Emerging Markets, „Ecoforum”, Vol. 5, No. 1(8), pp. 9-15.

[12] Iqbal J., Hameed W.U. (2020), Open Innovation Challenges and Coopetition-Based Open-Innovation Empirical Evidence From Malaysia, [in:] P. Ordoñez de Pablos, X. Zhang, K.T. Chui (eds.), Innovative Management and Business Practices in Asia, IGI Global, Hershey, s. 144-166.

[13] Krzywicka-Szpor K. (2003), Zarządzanie zmiana i okresem przejściowym, MT Biznes, Warszawa.

[14] Kucharski M., Majewski R. (2006), Czy przedsiębiorstwa globalne sa naprawdę globalne? Analiza rynku producentów samochodów $i$ wybranych przedsiębiorstw $z$ rankingu FT 500, Wydawnictwo Uniwersytetu Wrocławskiego, Wrocław.

[15] Lisiński M., Sroka W., Brzeziński P. (2021), Nowoczesne koncepcje zarządzania $w$ kierowaniu przedsiębiorstwami - wyniki badań, „Przegląd Organizacji”, Nr 1, s. 26-30.

[16] Lukitowati R., Ramli K. (2020), Assessing the Information Security Awareness of Employees in PT ABC Against International Organization for Standardization (ISO) 27001: 2013, „Journal of Computational and Theoretical Nanoscience", Vol. 17, No. 2-3, pp. 1441-1446.

[17] Malewska K., Sajdak M. (2020), Intuicja w podejmowaniu decyzji a zdolność przedsiębiorstw do inicjowaniu zmian strategicznych - założenia do badań, „Przegląd Organizacji”, Nr 9, s. 11-18.

[18] Michna M. (2016), Zasoby ludzkie jako kluczowy czynników sukcesów w przedsiębiorstwach przyszłości, „Zeszyty Naukowe Politechniki Częstochowskiej. Zarządzanie”, Nr 23, T. 1, s. 130-136.

[19] Rotvold G. (2008), How to Create a Security Culture in Your Organization: A Recent Study Reveals the Importance of Assessment, Incident Response Procedures, and Social Engineering
Testing in Improving Security Awareness Programs, „Information Management Journal", Vol. 42, No. 6, pp. 32-38.

[20] Stoyanova T., Iliev I. (2017), Employee Engagement Factor for Organizational Excellence, "International Journal of Business and Economic Sciences Applied Research (IJBESAR)", Vol. 10, No. 1, pp. 23-29.

[21] Tahir N., Yousafzai I.K., Jan S., Hashim M. (2014), The Impact of Training and Development on Employees Performance and Productivity A case study of United Bank Limited Peshawar City, KPK, Pakistan, „International Journal of Academic Research in Business and Social Sciences", Vol. 4, No. 4, pp. 86-98.

[22] Vosloban R.I. (2012), The Influence of the Employee's Performance on the Company's Growth - A Managerial Perspective. Emerging Market Queries in Finance and Business, „Procedia Economics and Finance”, Vol. 3, pp. 660-665.

[23] Wisse B., van Eijbergen R., Rietzschel E.F., Scheibe S. (2018), Catering to the Needs of an Aging Workforce: The Role of Employee Age in the Relationship between Corporate Social Responsibility and Employee Satisfaction, ,Journal of Business Ethics”, Vol. 147, No. 4, pp. 875-888.

[24] Wolfmayr K. (2020), High Speed Strategy Implementation in a Global, Dynamic Business Environment, BSc. Thesis, Universität Linz, Linz.

\section{Global Corporate Strategy in the Context of Employee Awareness}

\section{Summary}

In the era of industrialisation, the company's global strategy plays a significant role in surviving in a competitive environment. Global strategy is a major advantage that allows you to compete with the competition and achieve a higher level of operational efficiency. In this context, the awareness of the global strategy among employees is of key importance. However, in most companies the level of awareness among employees is low, which has a negative impact on the global strategy. Hence, the aim of this study is to analyse the level of awareness among employees in relation to the global strategy of the company. Large enterprises operating in Poland were selected for the purpose of the study. A questionnaire was used to obtain the data. Finally, after collecting the data, 82 verified questionnaires were received with responses that were used in the data analysis performed. The survey results show a high level of employee awareness in relation to the global strategy of enterprises. According to employees, a global strategy is important for brand building, innovation and expansion into new markets. The employees believe that the main benefits of the global strategy include: improving the quality of products, increasing sales, promoting brand recognition, increasing profit, increasing the number of customers.

\section{Keywords}

global strategy, employee awareness, large enterprises, knowledge management 